\title{
University Management Information System (UMIS) Acceptance among University Student: Applying the Extended Technology Acceptance Model (ETAM)
}

\author{
Arumugam Raman \\ School of Educational Studies and Modern Languages, University Utara Malaysia \\ 06010 Sintok, Kedah, Malaysia \\ Tel: 60-4-928-4852Ｅ-mail: arumugam@uum.edu.my \\ Received: September 23, 2011 Accepted: October 15, 2011 Published: December 1, 2011 \\ doi:10.5296/jse.v1i1.990 URL: http://dx.doi.org/10.5296/jse.v1i1.990
}

\begin{abstract}
This study uses Extended Technology Acceptance Model (ETAM) to predict University Management Information System (UMIS) acceptance amongst postgraduate students. A model for UMIS acceptance is used to examine how various factors (technical support, and computer literacy) modified from Technology Acceptance Model (TAM) influence acceptance and its antecedents. This model is examined through an empirical study using structural equation modeling techniques. Results shows that perceived usefulness, perceived ease to use, technical support, and computer literacy were significant determinants of postgraduate students' UMIS acceptance. The current research found that a strong positive relationships between the technical support and the usage of IU (UMIS).
\end{abstract}

Keywords: Postgraduate students, Technology Acceptance Model (TAM), Perceived usefulness, Ease to use, Computer literacy, Technical support, University Management Information System (UMIS) 


\section{Introduction}

The proliferation of internet access and development in Web technology has prompted the University Utara Malaysia (UUM) to explore the web based applications. University Management Information System (UMIS) (www.umis.uum.edu.my) is a database designed to access information and make transactions. This database only can be accessed by authorised users from any location and at any time via Internet. Student can achieve information namely, Post Graduate Academic Affair (GAIS), System of Students Affair (SAIS), Student's account and General. Currently a total of 4556 students are using this portal and the number of users is growing.

The goal of this study is to explore postgraduate students' acceptance of UMIS. As with any other information system (IS), the success of online information access depends largely on user satisfaction and other factors (DeLone and McLean, 2003). This paper uses extended Technology Acceptance Model (TAM) (Davis, 1989) to predict UMIS acceptance amongst postgraduate students who form the biggest researcher group of the university.

\section{Literature review}

Davis (1986) introduces TAM in 1986 to explain technology adoption. The origins of the TAM came from Ajzen and Fishbein's (1975) theory of reasoned action (TRA). This theory describes how a person's specific behavior manifests based on his/her attitudes and beliefs. Davis included two constructs to establish the TAM. One of the construct is perceived usefulness (PU) and perceived ease of use (PEOU) (Davis, 1986; Davis, 1989). Technology acceptance is influenced by different variables. Latest researches include PU, computer confidence (Rovai \& Childress, 2002), training (Tsitouridou \& Vryza, 2003), gender (Sadik, 2006; Kwak \& McDaniel, 2011), knowledge about computers (Mukti, 2000), and computer experience (Potosky \& Bobko, 2001; Kumar \& Kumar, 2003). Prior research suggests that TAM needed to be extended by incorporating additional variables in order to improve its specificity and explanatory power (Hu et al., 1999; Moon \& Kim, 2001). Some studies have extended TAM and applied it to examine behavioural intention towards using learning management system (LMS) (Gefen et al., 2003; Vijayasarathy, 2004). However very little empirical work has been done to extend TAM and apply interactional factors.

The present study proposes two new variables specific to UMIS: computer literacy, and technical support. These two variables well represent UMIS features, such as user's computer knowledge, and technical support (technical support, equipment, faculty support). The purpose of this study is to apply the extended TAM to examine the postgraduate students' intention of UMIS usage. This study contributes to the TAM research by using computer literacy and technical support as independent variables to predictive of the UMIS usage.

Original TAM incorporates the acceptance of new technology in terms of two major constructs: i) PU and ii) PEOU. These two constructs influence the intention to use (IU) the UMIS. It is hoped that the findings of the study will build on existing insights of the TAM. Second, this study extends the TAM by including additional user-related variables such as computer literacy (CL) and technical support (TS). Third, this study has the potential to inform on the use of UMIS at postgraduate level an area of crucial importance in view of the 
increasing roles that computers play in teaching and learning. Through understanding the relationships among variables that influences postgraduate students' use of technology, course designers, instructors are better placed to prepare postgraduate students to use technology effectively for teaching and learning in the higher institutions.

\subsection{Related studies on Perceived usefulness (PU) and perceived ease of use (PEOU)}

Davis (1989) defined perceived usefulness and perceived ease to use as follows:

Perceived usefulness: The degree to which an individual believes that using a particular system would enhance his or her job performance.

Perceived ease to use: The degree to which an individual believes that using a particular system would free of physical and mental effort. Effort is an exertion of strength or power, whether physical or mental, in performing an act or aiming at an object.

A number of studies revealed the importance of perceived usefulness and perceived ease to use in forecasting human behaviour. Importance of perceived use could be found in the Tornatzky and Klein's (1982) on innovation adoption. Further Bandura (1982) proved the importance of considering both perceived usefulness and perceived ease to use in predicting a person's behaviour. Previous researches (Segars and Grover, 1993; Igbaria et al., 1995, 1996, 1997; Ndubusi et al., 2001; Ramayah et al., 2002, 2003, 2003, 2005; Lee et al., 2005; Liu et al., 2005; Pituch and Lee, 2006; Saadé et al., 2007; Ramayah \& Mastura, 2008) proved that perceived usefulness influence the technology usage of a person. Perceived ease of use was a significant predictor of intention to use mobile services in Norway (Nysveen , 2005). Other researches also have found ease of use to be influential in system usage (Adams et al., 1992; Davis, 1989; Koay, 2002; Ramayah et al., 2002; Ramayah et al., 2005). Results from these and other studies suggest that adequate explanation and/or prediction of user acceptance of technology. While perceived usefulness has been identified as consistently important in attitude formation, support for perceived ease to use has been inconsistent and less significance.

Ho1: There is a positive relationship between perceived usefulness and intention to use UMIS.

Ho2: There is a positive relationship between perceived ease of use and intention to use UMIS. 


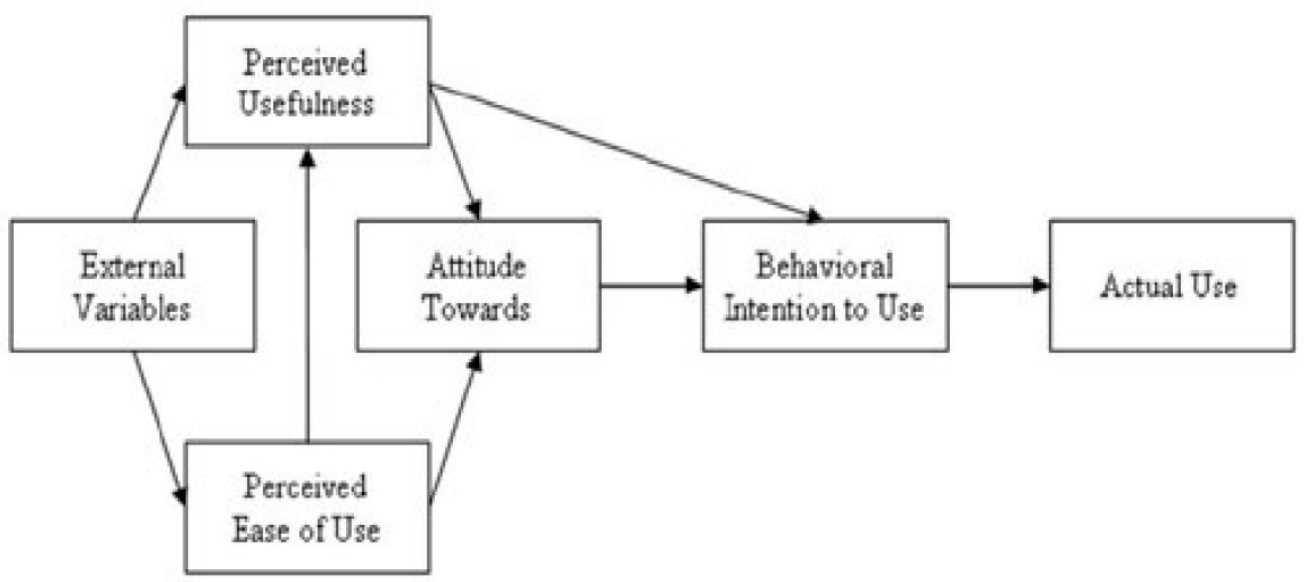

Ho3: There is a positive relationship between perceived usefulness and intention to use UMIS.

\subsection{Technical support (TS)}

Technical support is an external constraint that affects a user's behavioral intention to use. Technical support refers to the easy access of technological infrastructure and resources. Davis et al. (1989) propose that technical support is an important variable likely to affect perceived usefulness and perceived ease of use. Pare' and Elam (1995) found a positive relationship between technical support and usage. Pare' and Elam (1995) describe a positive relationship between technical support and ease of use. Absence of the proper technical support, users might be left trying to address technical difficulties themselves, which will likely make them less motivated and make them less productive. Poor technical support, technology use may deleteriously affect intention to use mobile banking (Ahearne et al., 2005). Therefore:

Ho4: There is positive relationship between technical support and intention to use UMIS.

\subsection{Computer literacy (CL)}

Webopedia (www.webopedia.com) defined computer literacy as "the level of expertise and familiarity someone has with computers. Computer literacy generally refers to the ability to use applications rather than to program. Individuals who are very computer literate are sometimes called power users.

The important criteria for becoming computer literate have included computer awareness (Anderson \& Klassen, 1981; Battista \& Steele, 1984; Johnson, Anderson, Hansen, \& Klassen, 1980), programming ability (Cheng, Plake, \& Stevens, 1985; Gabriel, 1985a, 1985b; Galanter, 1984; Haigh, 1985; Luehrmann, 1981), and competency in computer software applications (Ganske \& Hamamoto, 1984; Hasset, 1984; Levin, 1983; Meierhenry, 1982; Pickert \& Hunter, 1983). Venkatesh and Davis (1994) found system characteristics did not play a significant role in the formation of early ease of use perceptions for the novice users of a two different systems. The ease of use of two different systems did not differ significantly before direct experience, but after direct experience, system characteristics did become significant determinant of ease of use perceptions. There is exists empirical support to suggest that computing experience, computing support and coaching determines perceptions. Prior 
experience has been found to be an important determinant of behaviour (Bagozzi, 1981). Therefore:

Ho5: There is positive relationship between computer literacy and intention to use UMIS.

\subsection{Intention to use UMIS (IU)}

In this study, user acceptance is determined by intention to use due to the fact that UMIS is characterized by moderate adoption and limited use. This construct comes from the TAM model. The researcher believed that investigation of intention to use would enhance the predicting power of the research model. This study is focusing on theoretical rationale for other two constructs and their causal relationships to the primary dependent variable (intention to use).

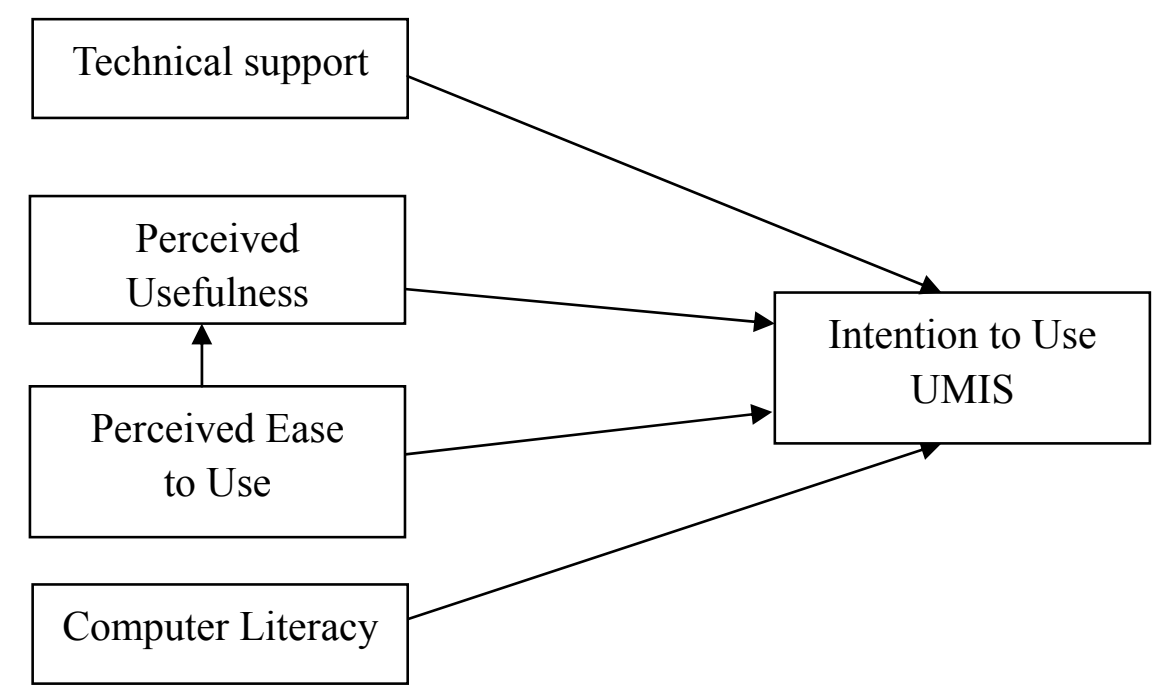

\section{Research Methodology}

Figure 1. Proposed research model

The survey is conducted in a Malaysian context. The populations of this study consisted of all postgraduate students enrolled with University Utara Malaysia. A structured questionnaire consisting five parts (usage of UMIS, demographic, technical support, perceived usefulness, perceived ease to use, and computer literacy) was used to collect the data for this study using a convenience sampling. The researcher sent questionnaire via e-mail to 250 postgraduate students. However, only 120 (48\%) valid responses received. Several studies (Boomsma, 1982; Bollen, 1989) have recommended that for Structure Equation Model (SEM) analysis, a sample size from 100 to 120 is appropriate. The instrument was composed of 18 statements on PU (four items), PEOU (four items), TS (three items), CL (five items) and IU (two). All measurements scale items were obtained directly from the previous studies. The scale used for perceived usefulness and perceived ease of use ranged from 1 to 7 , whereas for usage, computer literacy, and technical support ranged from 1 to 5 . The appendix details the questionnaire. Participants from various intact classes completed the survey questionnaire provided by researcher. All the potential respondents were briefed on the aim of the study and their rights not to participate in the study. 


\section{Data analysis}

Of the participants, 49 percent were males, 51 percent, females with average age 29; the age range extends from 20 to 55. Eighty five percent of the respondents are full time postgraduate students. They were selected from different programmes: One year full time postgraduate diploma in education(10.5\%), two year Masters in Education (part time and full time) $(25.5 \%)$, two year Masters in Information Technology (21.5\%) and Masters in Business Administration $(30.0 \%)$ other master's degree programmes $(12.5 \%)$. Almost every student had access to a intern et at home (89\%) and the mean years of computers usage is 9.5 years $(\mathrm{SD}=2.53)$.

The descriptive statistics of the measurement items are shown in Table 1. All scales in this study were highly reliable. The four-item PEOU scale had a Cronbach $\alpha$ realibility of 0.905 ; the two-item PU scale had a reliability of 0.931 . The two-item IU scale had a Cronbach $\alpha$ coefficient of 0.911. For the five-item CL scale had a Cronbach $\alpha$ coefficient of 0.897 , and that TS three-item was 0.852 . All of the Cronbach $\alpha$ coefficient's exceeded 0.80 , therefore the scales acceptably reliable (Peterson, 1994).

Item reliability was assessed by its factor loading

Table 1. Reliablity of Scales

\begin{tabular}{|l|l|l|l|l|l|}
\hline \multicolumn{2}{|l|}{ Scales adapted from } & Cronbach $\alpha$ & Means & SD & Number of items \\
\hline PU & Venkatesh \& Davis (2000) & 0.931 & 4.49 & 1.45 & 4 \\
\hline PEOU & Venkatesh \& Davis (2000) & 0.905 & 4.52 & 1.32 & 4 \\
\hline IU & Venkatesh \& Davis (2000) & 0.911 & 4.91 & 1.65 & 2 \\
\hline CL & This study & 0.897 & 4.31 & 1.09 & 5 \\
\hline TS & This study & 0.852 & 3.94 & 1.58 & 3 \\
\hline
\end{tabular}

Note: The scale used for perceived usefulness and perceived ease of use ranged from 1 to 7 , whereas for usage, computer literacy, and technical support ranged from 1 to 5 .

\subsection{Realibility}

The item reliability was assessed by its factor loading. Hair et al. (2006) suggested that an item is significant if its factor loading is greater than 0.50 . Table 2 shows the eigenvalues of all contructs more than 1.00 and the percent of cumulative variance was $56 \%$. The factor loadings of all the items in the measure ranged from 0.63 to 0.85 . This exceeds the benchmark set by Hair et al. (2006). 
Table 2. Factor loadings of the measurement items

\begin{tabular}{llll}
\hline & Rotated factor loading & Eigenvalue & \% variance explained \\
\hline PU1 & 0.801 & & \\
PU2 & 0.822 & & \\
PU3 & 0.745 & 3.426 & 19.024 \\
PU4 & 0.724 & & \\
\hline PEOU5 & 0.725 & & \\
PEOU6 & 0.813 & & \\
PEOU7 & 0.721 & 2.838 & \\
PEOU8 & 0.821 & & \\
\hline IU1 & 0.811 & 1.746 & \\
IU2 & 0.752 & & \\
\hline CL1 & 0.648 & & \\
CL2 & 0.724 & & \\
CL3 & 0.711 & & \\
CL4 & 0.779 & & \\
CL5 & 0.647 & 2.154 & \\
\hline TS1 & 0.702 & & \\
TS2 & 0.892 & & \\
TS3 & 0.833 & 2.523 & \\
\hline
\end{tabular}

In this study, an acceptable level of discriminate validity at the item level was found. Fornall and Larcker (1981) suggested the square root of the average variance extracted (AVE) from the construct should be greater than the correlation shared between the constructs and other constructs in the model. Table 3 shows correlation among the constructs in the model, with the square roots of AVE on the diagonal. All these diagonal values greater than the off-diagonal values; hence the test of discriminant validity acceptable.

Table 3. Construct correlation matrix

\begin{tabular}{lllllll}
\hline & & \multicolumn{2}{l}{ Construct } \\
\cline { 3 - 6 } Construct & AVE & PU & PEOU & CL & TS & IU \\
\hline PU & 0.75 & $\mathbf{0 . 8 7}$ & & & & \\
PEOU & 0.71 & 0.74 & $\mathbf{0 . 8 4}$ & & & \\
CL & 0.65 & 0.52 & 0.67 & $\mathbf{0 . 8 1}$ & & \\
TS & 0.77 & 0.48 & 0.61 & 0.59 & $\mathbf{0 . 8 8}$ & \\
IU & 0.67 & 0.62 & 0.68 & 0.75 & 0.55 & $\mathbf{0 . 8 2}$ \\
\hline
\end{tabular}

Note: Diagonal: Square root of average variance extracted (AVE) from observed variables (items).Off-diagonal elements are the correlations between constructs. PU, perceived usefulness; PEOU, perceived ase of use; CL, Computer literacy; TS, Technical support; IU, Intention to use,

Data analysis involved structural equation (SEM) using AMOS 7.0. Five model-fit indexes were used to examine a series of dependence especially direct and indirect effects among the 
constructs within the model (Hair et al. 2006). These are the $\left(\chi^{2} / \mathrm{df}\right)$, Goodness of Fit Index (GFI), Normed Fit Index (NFI), Standardized Root Mean Residual (SRMR), and the comparative Fit Index (CFI). Table 4 summarizes the level of acceptable fit and the fit indices for the proposed research model in this study.

Table 4. Overall model fit indices of the proposed research model

\begin{tabular}{lll}
\hline Model fit indices & Recommended value & Results \\
\hline$\chi^{2}$ & $\chi^{2} /$ d.f. $=5^{*}$ & $3.92^{* *}$ \\
GFI & $>0.90$ & 0.931 \\
NFI & $<0.90$ & 0.918 \\
SRMR & $<.0 .10$ & 0.065 \\
CFI & $>0.90$ & 0.951 \\
\hline
\end{tabular}

All the values satisfied the recommended level of acceptable fit. The significance of individual path was assessed and summarized in Figure 2. All hypotheses were supported by the data. The paths exhibited a P-value of $<0.01$. As hypothesized, PU, PEOU, CL and TS with path coefficients $0.41,0.37,0.43$ and 0.51 , significantly influence IU. The model accounts for $39 \%\left(R^{2}=0.39\right)$ of the variance of IU.

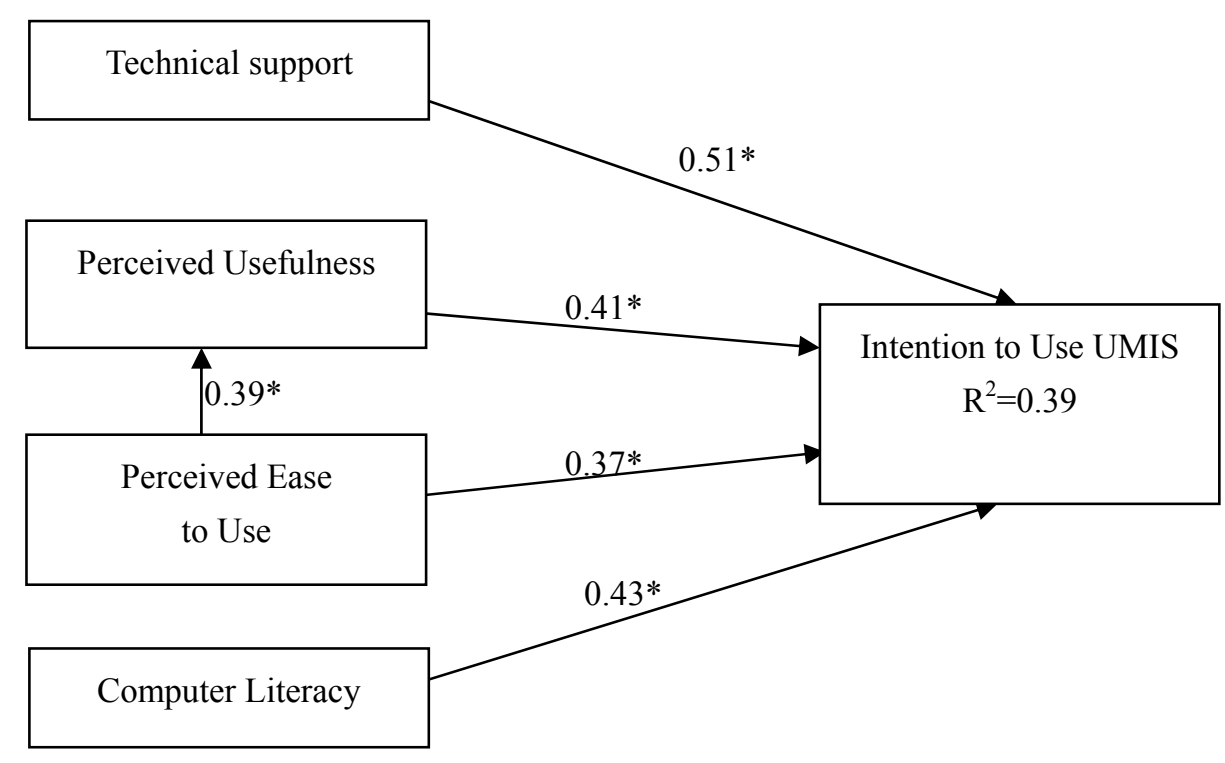

Figure 2. SEM analysis of the research model

\section{Discussion}

The results provide strong support for the theoretical model of relationship among perceived usefulness, perceived ease of use, computer literacy and technical support towards intention to use UMIS.

The findings show that usage of UMIS by postgraduate students is driven directly by their perception of the system's usefulness, perceived ease of use, their computer literacy, and technical support provided by systems administrators. 


\subsection{Effects of perceived usefulness and ease of use on UMIS usage}

This study reveals that postgraduate students PU had significant effects on IU (UMIS) usage. IT supports the recent research that PU to be the major determinant on IU (e.g. Agarwal and Prasad (1999); Chau and Hu (2002); Davis, et al. (1989); Hu et al. (1999); Igbaria et al. (1995); Igbaria (1993); Mathieson (1991); Mathieson et al. (2001); Moon and Kim (2001); Ramayah et al. (2002); Venkatesh and Davis (2000) also reported that PU is significant and positively influences the behavioral intent. Further this study found that postgraduate students viewed computers are necessary tool and their attitude were significantly influence the intention to use UMIS. Similar to PU, PEOU plays a major role in UMIS usage. PEOU associated to user friendliness of the UMIS. Error free and low download time enhance the usage of UMIS.

\subsection{Effects perceived ease of use on perceived usefulness and UMIS usage}

Previous studies found contradictory relationship between perceived ease of use and perceived usefulness. A study by Gefen and Straub (1997) revealed that the relationship between e-mail acceptances as a technology is not significant whereas others (e.g. Jantan, Ramayah \& Chin, 2001; Moon \& Kim, 2001) proved that significant relationship exists. Although UMIS was perceived as easy to use, postgraduate students may perceive them as useful. Conversely, UMIS is perceived to be useless to postgraduate students if they believe that they do not know how to use them.

\subsection{Computer literacy}

This study found that a significant influence of postgraduate students computer literacy on their UMIS usage, suggesting that postgraduate students perceive that their effort have some effect on their computer environment. Further, students who are more 'computer literate' perceive themselves as having more control over than students are were novices by virtue of their application knowledge.

\subsection{Technical support}

The current research found that the positive relationships between the technical support and the usage of IU (UMIS). In brief technological support is an important factors in analyzing continuous intention to use (i.e., whether or not postgraduate students would continue to use UMIS). Technological support exerts a prominent influence on postgraduate students' intention to use UMIS (i.e., continuous intention to use). That is, the degree to which a person wishes to use UMIS again can be increased or decreased depending on technological aspects such as easy to use user interface, easy access to the Internet, security concerns, and so on. This observation implies that UUM should attempt to provide well-established technological infrastructure and service environments in order to promote the widespread use of their UMIS services.

\section{Conclusion}

Student's intention to use technology has been explored by various studies. This research has unique implications for the academic portal administrators. This study considers perceived usefulness and perceived ease of use, two main factors in TAM, in analyzing why and how 
someone forms an intention to use academic portal such as UMIS on a continuous basis. In addition, the study performs a practical experiment to examine the role of an individual's computer literacy, and technical support, in UMIS usage. The analysis demonstrates that even though they are both important factors, system administrators should focus more on technological support because it exerts a strong influence on continuous intention to use. Therefore system administrators should devise strategic plan to provide technical support for the postgraduate students.

There are some empirical limitations to this study, as is the case with most research. First, postgraduate students UMIS adoption was measured by intention to use. Even though previous studies have mainly employed a student's intention as a substitute for actual usage, there has also contrary perspective among scholars about of this practice. Therefore the result of this study should be interpreted with prudence. Second, this study took place within the Malaysia tertiary education setting. Since all government funded Malaysia universities use standard curriculum and same semester system this study may reflect Malaysian post graduate students' intention to use of their university management information system (the name can be vary based on university management). Different result may generate if the same research carried out in different cultural setting. It is suggested that future studies consider the effects of experience and technical support in various cultural contexts.

\section{References}

Adams, D.A., Nelson, R.R. \& Todd, P.A. (1992). Perceived usefulness, ease of use and usage of information technology: A replication. MIS Quarterly, 16: 227-247. http://dx.doi.org/10.2307/249577

Agarwal R, \& Prasad J. (1999). Are individual differences germane to the acceptance of new information technologies. Decis Sci, 30(2), 361-91. http://dx.doi.org/10.1111/j.1540-5915.1999.tb01614.x

Ahearne, M., Jelinek, R., \& Rapp, A. (2005). A moving beyond the direct effect of SFA adoption on salesperson performance training and support as key moderating factors. $\begin{array}{lllll}\text { Industrial } \quad \text { Marketing } & \text { Management, } & 34, & 379-\end{array}$ http://dx.doi.org/10.1016/j.indmarman.2004.09.020

Ajzen, I., Fishbein, M. (1980). Understanding Attitudes and Predicting Social Behavior, Prentice-Hall, Englewood Cliffs: NJ

Anderson, R. E., \& Klassen, D. L. (1981). A conceptual framework for developing computer literacy instruction. AEDS Journal, 14, 128-143.

Bandura. A. (1982). Self-efficacy mechanism in human agency. American Psychologist, 37 , 122- 147. http://dx.doi.org/10.1037/0003-066X.37.2.122

Bagozzi, R.P. (1981). Attitudes, intentions, and behaviour: a test of some key hypotheses", Journal of Personality and Social Psychology, Vol. 41 pp.607-27. http://dx.doi.org/10.1037/0022-3514.41.4.607 
Battista, M. T., \& Steele, K. J. (1984). The effect of computer-assisted and computer programming instruction on the computer literacy of high ability fifth grade students. School $\begin{array}{llll}\text { Science } \quad \text { and } & \text { 84t(8), }\end{array}$ http://dx.doi.org/10.1111/j.1949-8594.1984.tb09580.x

Bollen, K.A. (1989). Structural equations with latent variables. Wiley-Interscience: New York.

Boomsma, A. (1982). The robustness of LISREL against small sample sizes in factor analysis model. In Systems under indirect observation causality structure, Joreskog KG. Wold, H. (eds.), North-Holland: Amsterdam

Chau, P.Y.K., \& Hu, P.J. (2001). Information Technology Acceptance by Individual Professionals: A Model Comparison Approach, Decision Sciences, 32(4), 699-719. http://dx.doi.org/10.1111/j.1540-5915.2001.tb00978.x

Cheng, T. T., Plake, B., \& Stevens, D. J. (1985). A validation study of the computer literacy examination:Cognitive aspect. AEDS Journal, 18(3), 139151.

Davis, F. D. (1986). A technology acceptance model for empirically testing new end-user information systems: Theory and results. Doctoral dissertation. Cambridge, MA: MIT Sloan School of Management.

Davis, F. D. (1989). Perceived usefulness, perceived ease of use, and user acceptance of information technology. MIS Quarterly, 13(3), 319-339. http://dx.doi.org/10.2307/249008

Davis, F.D., Bagozzi R.P., \& Warshaw P.R. (1989). User acceptance of computer technology: a comparison of two theoretical models. Management Science, 35, 982-1003 http://dx.doi.org/10.1287/mnsc.35.8.982

DeLone, W.H. \& Mclean, E.R. (2003). The DeLone and McLean model of information system success: a ten-year update. Journal of Management Information Systems, 19, 9-30.

Fishbein, M. \& Ajzen, I. (1975). Belief, Attitude, Intentions and Behaviour: An Introduction to Theory and Research, Addison-Wesley, Reading, MA.

Fornell C. \& Larcker D.F. (1981) Evaluating structural equation models with unobservable variables and measurement error. Journal of Marketing Research, 48, 39-50. http://dx.doi.org/10.2307/3151312

Gabriel, R. M. (1985b). Computer literacy assessment and validation: Empirical relationships at both student and school levels. Journal of Educational Computing Research, 1(4), 415-425. http://dx.doi.org/10.2190/CQ0A-0YMT-J10G-5WBV

Galanter, E. (1984). Homing in on computers. Psychology Today, 30-33, September.

Ganske, L., \& Hamamoto, P. (1984). Response to crisis: A developer's look at the importance of needs assessment to teacher educators in the design of computer literacy training programs. Educational Computer Technology Journal, 32(2), 101-113. 
Gefen, D., Karahanna, E., \& straub, D.W. (2003) Trust and TAM in online shopping: an integrated model. MIS Quaterly, 27, 51-90

Gefen, D. \& Straub, D.W. (1997). Gender differences in the perception and use of e-mail: an extension to the technology acceptance model. MIS Quarterly, 21 (4), 389 - 400. http://dx.doi.org/10.2307/249720

Haigh, R. W. (1985). Planning for computer literacy. Journal of Higher Education, 56(2), 161-171. http://dx.doi.org/10.2307/1981664

Hair J.F., Jr, Black B., Babin B.J., Anderson R.E. \& Tatham R.L. (2006) Multivariate Data Analysis, (6th ed). Prentice Hall, Upper Saddle River, NJ.

Hasset, J. (1984). Computers in the classroom. Psychology Today, 22-28, September.

Hu P.J., Clark T.H.K. \& Ma W.W. (2003) .Examining technology acceptance by school teachers: a longitudinal study. Information and Management 41, 227-241. http://dx.doi.org/10.1016/S0378-7206(03)00050-8

Hu, P.J., Chau, P.Y.K., Sheng, O.R.L. \& Tam, K. Y. (1999). Examining the technology acceptance model using physician prance of telemedicine. Journal of Management Information Systems, 16 (2), 91-112.

Igbaria, M., Iivari, J. \& Maragahh, H. (1995). Why do individuals use computer technology? A Finnish case study. Information and Management, 29(5): 227-238. http://dx.doi.org/10.1016/0378-7206(95)00031-0

Igbaria, M., Parasuraman, S. \& Baroudi, J.J. (1996). A motivational model of microcomputer usage. Journal of Management Information Systems, 13(1): 127-143.

Igbaria, M., Zinatelli, N., Cragg, P. \& Cavaye, A.L.M. (1997). Personal computing acceptance factors in small firms: A structural equation modeling. MIS Quarterly, 21(3): 279-305. http://dx.doi.org/10.2307/249498

Jantan, M., Ramayah, T., \& Chin, W.W. (2001). Personal Computer Acceptance by Small and Medium Companies Evidence from Malaysia, Jurnal Manajemen \& Bisnis, 3(1), 1-14.

Johnson, D. C., Anderson, R. E., Hansen, T. P., \& Klassen, D. L. (1980,February). Computer literacy--what is it? Mathematics Teacher, 91-96.

Kumar P. \& Kumar A. (2003). Effect of a web-based project on pre-service and in-service teachers' attitude toward computers and their technology skills. Journal of Computing in Teacher Education 19, 87-91.

Kwak, D. H., \& McDaniel, S. R. (2011). Using an extended Technology Acceptance Model in exploring antecedents to adopting fantasy sport league websites. International Journal of Sports Marketing and Sponsorship, 12(3), 240-253

Lee, M. K. O., Cheung, C. M. K., \& Chen, Z. (2005). Acceptance of Internet-based learning medium: The role of extrinsic and intrinsic motivation. Information \& Management, 42, 
1095-1104. http://dx.doi.org/10.1016/j.im.2003.10.007

Levin, D. (1983,March). Everyone wants 'computer literacy' so maybe we should know what it means. The American School Board Journal, 25-28.

Liu, S., Liao, H., \& Peng, C. (2005). Applying the technology acceptance model and flow theory to online e-learning users' acceptance behavior. Issues in Information Systems, 6(2), $175-181$.

Luehrrnann, A. (1981, December). Computer literacy: What should it be? Mathematics Teacher, 682-686.

Mathieson, K. (1991). Predicting user intentions: Comparing the technology acceptance model with the theory of planned behavior. Information Systems Research, 2(3): 173-191. http://dx.doi.org/10.1287/isre.2.3.173

Mathieson, K., Peacock, E. and Chin, W. (2001). Extending the Technology Acceptance Model: The influence of perceived user resources. The Database for Advances in Information Systems. 32 (3).

Meierhenry, W. C. (1982, December). Microcomputers and adult education. Training and Developmental Journal, 58-66.

Moon, J. \& Kim, Y. (2001). Extending the TAM for a World-Wide-Web context. Information and Management, 38, 217-230. http://dx.doi.org/10.1016/S0378-7206(00)00061-6

Mukti N.A. (2000) Computer technology in Malaysia: teach-ers' background characteristics, attitudes and concerns. Electronic Journal of Information Science in Developing Countries 3, $1-13$.

Ndubisi, N.O., Jantan, M. \& Richardson, S. (2001). Is the technology acceptance model valid for entrepreneurs? Model testing and examining usage determinants. Asian Academy of Management Journal, 6(2): 31-54.

Nysveen, H., Pedersen, P.E. \& Thorbjornsen, H. (2005). Explaining intention to use mobile chat services: Moderating effects of gender. Journal of Consumer Marketing, 22(5): 247-256. http://dx.doi.org/10.1108/07363760510611671

Pare', G., \& Elam, J. (1995). Discreationary use of personal computers by knowledge workers: testing of a social psychology theoretical model. Behaviour \& Information Technology, 14, 215-228. http://dx.doi.org/10.1080/01449299508914635

Peterson, R.A.(1994). A meta analysis of Cronbach's coefficients alpha. Journal of Consumer Research, 21, 381- 391. http://dx.doi.org/10.1086/209405

Pickert, S. M., \& Hunter, B. (1983). Redefining "literacy." Momentum, 14(3), 7-9.

Pituch, K.A, \& Lee, Y.-K. (2006). The influence of system characteristics on e-learning use. Computers Education, 47, 222-244. http://dx.doi.org/10.1016/j.compedu.2004.10.007

Potosky D. \& Bobko P. (2001) A model for predicting computer experience from attitudes 
toward computers. Journal of Business and Psychology 15, 391- 404. http://dx.doi.org/10.1023/A:1007866532318

Ramayah, T., Dahlan, N., Mohamad, O. \& Siron, R. (2002). Technology usage among owners/managers of SME's: The role of demographic and motivational variables. The proceedings of the 6th Annual Asian-Pacific Forum for Small Business on Small and Medium Enterprises Linkages, Networking and Clustering, Kuala Lumpur, Malaysia, 16- 18 October.

Ramayah, T., Jantan, M. \& Bushra, A. (2003). Internet usage among students of institutions of higher learning: The role of motivational variables. The Proceedings of the 1stInternational Conference on Asian Academy of Applied Business Conference, Sabah, Malaysia, 10-12 July.

Ramayah, T. \& Osman, M. (2005). Complementing classroom teaching with an internet course website: Does gender and race matter. Proceedings of the 5th South East Asia Association for Institutional Research Conference. Westin Resort Nusa Dua, Bali, Indonesia, 14-16 September.

Ramayah, T. \& Mastura. (2008). Technology usage among construction students the moderating role of gender. Journal of Construction in Developing Countries, 13, 63 - 77.

Rovai A.P. \& Childress M.D. (2002) Explaining and predict-ing resistance to computer anxiety reduction among teacher education students. Journal of Research on Technology in Education 35, 226-235.

Saadé, R. G., Nebebe, F., \& Tan, W. (2007). Viability of the technology acceptance model in multimedia learning environments: Comparative study. Interdisciplinary Journal of Knowledge and Learning Objects, 37, 175-184.

Sadik A. (2006) Factors influencing teachers' attitudes toward personal use and school use of computers: new evidence from a developing nation. Evaluation Review 30, 86-113. http://dx.doi.org/10.1177/0193841X05276688

Segars, A.H. and Grover, V. (1993). Re-examining perceived ease of use and usefulness: A confirmatory factor analysis. MIS Quarterly, 17(1): 517-725. http://dx.doi.org/10.2307/249590

Venkatesh, V., Davis, F.D. (1994). Modeling the determinants of perceived ease of use, Proceedings of the International Conference on Information Systems, Vancouver, pp.213-27.

Venkatesh, V. and Davis, F.D. (2000). A theoretical extension of the Technology Acceptance Model: Four longitudinal field studies. Management Science, 46(2): 186-204. http://dx.doi.org/10.1287/mnsc.46.2.186.11926

Vijayasarathy, L.R. (2004). Predicting consumer intentions to use on-line shopping: the case for an augmented technology acceptance model. Information and Management, 41, 747 762. http://dx.doi.org/10.1016/j.im.2003.08.011 
Webopedia. (n.d.). In Free online dictionary. Retrieved from http://www.webopedia.com/TERM/C/computer_literacy.html

Appendix: Measurement items

\begin{tabular}{|l|l|}
\hline Construct & Item \\
\hline $\begin{array}{l}\text { Perceived usefulness (adapted from } \\
\text { Davis }\end{array}$ & PU - Using UMIS will improve my studies \\
\hline & PU2 - Using UMIS will enhance my effectiveness \\
\hline & PU3 - Using UMIS will increase my productivity \\
\hline $\begin{array}{l}\text { Perceived ease of use (adapted } \\
\text { from Davis 1989) }\end{array}$ & $\begin{array}{l}\text { PEOU1 - My interaction with UMIS is clear and } \\
\text { understandable }\end{array}$ \\
\hline & $\begin{array}{l}\text { PEOU2 - I find easy to get in to system to do what i } \\
\text { want to do }\end{array}$ \\
\hline PEOU3 - The interaction with UMIS does not require a \\
lot of mental effort
\end{tabular}

\section{Copyright Disclaimer}

Copyright reserved by the author(s).

This article is an open-access article distributed under the terms and conditions of the Creative Commons Attribution license (http://creativecommons.org/licenses/by/3.0/). 